\title{
Heat Tolerance and Holding Ability in Broccoli
}

\author{
D.W. Heather ${ }^{1}$, J.B. Sieczka², M.H. Dickson ${ }^{3}$, and D.W. Wolfe ${ }^{4}$ \\ Department of Fruit and Vegetable Science, Cornell University, Ithaca, NY 14853
}

Additional index words. Brassica oleracea, floral induction, harvest concentration, heat stress, quality

\begin{abstract}
Forty hybrid broccoli [Brassica oleracea L. (Italica Group)] accessions were screened for heat tolerance and holding ability over three planting dates in 1988 at the Long Island Horticultural Research Laboratory in Riverhead, N.Y. Holding periods were quantified using the number of consecutive days between the time individual heads reached $10 \mathrm{~cm}$ diameter and cutting, which occurred when the sepals had fully expanded and had just begun to separate. In 1989 and 1991, heat stress was applied at various weeks during maturation to determine the most sensitive stage or stages of plant development in terms of reduction in holding period and head weight. Field studies and heat stress experiments indicate that heat stress may be most critical during the time the immature inflorescence measures 5 to $10 \mathrm{~mm}$ in diameter. This stage corresponds to $\approx 3$ weeks before harvest for summer plantings in the northeastern United States.
\end{abstract}

Broccoli production and consumption in the United States has risen dramatically over the past several decades. Land in production has tripled over the past 30 years with a remarkable $160 \%$ rise in consumption in 1983 alone (Love, 1986). While $90 \%$ to $95 \%$ of the total production remains in California, increased demand has resulted in an expansion of production into such areas as Mexico, Texas and to a lesser extent, parts of the northeastern United States. With increased interest in producing broccoli during the hot summer months, the need for cultivars with consistently good heat tolerance and holding ability is great.

The effect of low temperature on premature flowering of broccoli has been well documented (Fontes et al., 1967; Gauss and Taylor, 1969; Miller et al., 1985), but less is known about the hastening of flowering by high temperature during maturation. Fontes et al. (1967) reported that floral initiation does not occur at temperatures $>24 \mathrm{C}$. This result refers, however, to a continuous temperature threshold and not to the mean of a diurnal pattern as occurs in the field. Further, the broccoli shoot tip temperature is higher than surrounding air temperatures during the day and lower than air temperatures at night (Fujime and Hirose, 1984).

The shoot apex exhibits increased sensitivity to floral induction temperatures during the postjuvenile stage of broccoli development (Fontes et al., 1967; Miller et al., 1985). Even without low temperatures during the early postjuvenile growth stage, high temperatures during the onset of heading may have a significant impact on the concentration and duration of harvest. Variety trials from Canada to Australia have consistently shown significant effects of sowing time on the harvest concentration and environmental stability of yield (Chung, 1985; Knott and Hanna, 1949; Shattuck et al., 1986; Sieczka et al., 1989). Three typical physiological symptoms of heat stress in broccoli are the

Received for publication 6 Dec. 1991. Accepted for publication 15 June 1992. Paper \#19 of the Dept. of Fruit and Vegetable Science, Cornell University. A portion of a thesis submitted by D.W.H. as partial fulfillment of the requirements for the MS degree at Cornell Univ. We gratefully acknowledge the technical assistance provided by Robert Neese and Mark Sisson. The cost of publishing this paper was defrayed in part by the payment of page charges. Under postal regulations, this paper therefore must be hereby marked advertisement solely to indicate this fact.

'Graduate Research Assistant. Present address: Dept. of Plant Breeding, Cornell Univ., Ithaca, NY 14853.

${ }^{2}$ Associate Professor. Dept. of Fruit and Vegetable Science, Long Island Horticultural Research Laboratory, Riverhead, NY 11901.

${ }^{3}$ Professor. Dept. of Horticultural Sciences, NYS Agricultural Experiment Station, Cornell Univ., Geneva, NY 14456.

${ }^{4}$ Associate Professor. Dept. of Fruit and Vegetable Science. rapid swelling or puffing of sepals, irregular separation of individual florettes on the head, and the protrusion of upper leaves through the head.

Despite advances made through breeding, heat tolerant cultivars often perform quite -differently when grown in diverse locations. One objective of this study was to screen 40 hybrid broccoli accessions for heat tolerance and holding ability under Long Island conditions over three planting dates in 1988. The top eight entries were again tested over the same three planting dates in 1989. Harvest concentration was assessed to provide a more useful selection criterion than simply holding period alone. Controlled environment studies were also done to better understand what stages of growth and development are most susceptible to heat stress.

\section{Materials and Methods}

Field trials. In 1988, 14 commercial and 26 experimental hybrid broccoli accessions were obtained for field evaluations at the Long Island Horticultural Research Laboratory in Riverhead. Most of the experimental entries were bred specifically for heat tolerance and holding ability. The top eight selections were advanced to 1989 experiments for further evaluation using

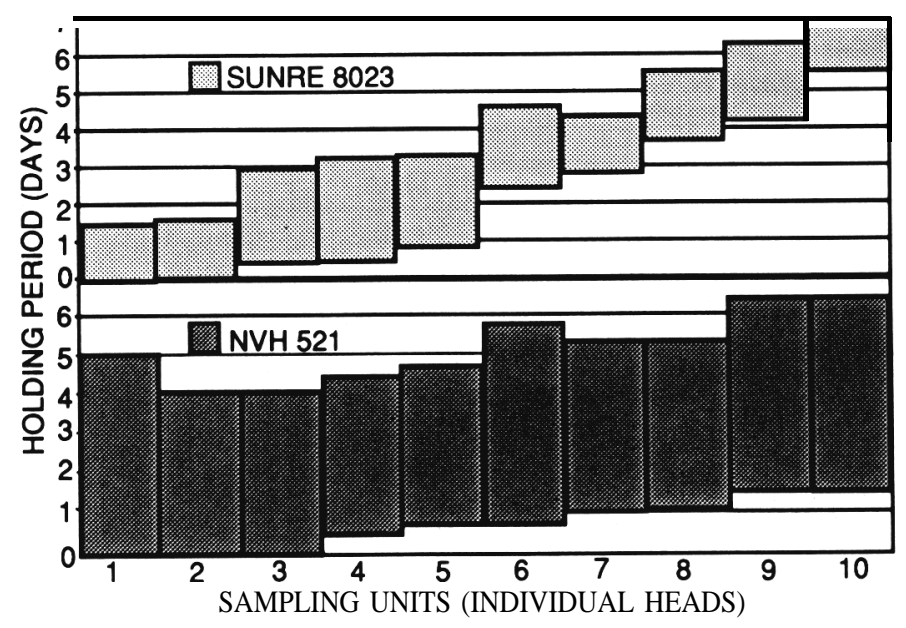

Fig. 1. Contrasting harvest concentration for two hybrid broccoli entries of the same maturity. The bottom of the bars indicates tagging of individual heads when they had reached $10 \mathrm{~cm}$ diameter; the top of the bars indicates cutting at earliest observed sepal separation. Data are the mean holding days through time of four replications in the second planting of 1988 . 
the same screening criteria as in 1988. Selection was based primarily on length and uniformity of the holding period, but was also based on head weight and marketable appearance.

Three plantings were sown in a Riverhead sandy loam (coarseloamy, mixed, mesic Typic Dystrochrepts) on 9 May, 30 May, and 13 June in 1988 and 1989. The experiments were arranged in a randomized complete block with four replications. The experimental unit consisted of one row per entry and guard rows surrounded the perimeter of each block. All plantings were direct seeded in rows $6 \mathrm{~m}$ long with a cone seeder in 1988 and with a precision belt seeder in 1989. Plants were hand-thinned to $30 \mathrm{~cm}$ apart in the row after 3 weeks. The between-row spacing was $86 \mathrm{~cm}$ and data were collected from the center 3 $\mathrm{m}$ of each row. The wide spacing between plants was done to minimize plant-to-plant interaction and to allow full expansion

Table 1. Average temperatures ${ }^{2}$ and total precipitation for broccoli sown over three planting dates ${ }^{y}$ in 1988 and 1989, Riverhead, N.Y.

\begin{tabular}{|c|c|c|c|c|c|c|c|c|}
\hline \multirow[b]{3}{*}{ Date } & \multicolumn{6}{|c|}{ Air temperature $\left({ }^{\circ} \mathrm{C}\right)$} & \multirow{2}{*}{\multicolumn{2}{|c|}{$\begin{array}{c}\text { Precipitation } \\
(\mathrm{mm})\end{array}$}} \\
\hline & \multicolumn{2}{|c|}{ High } & \multicolumn{2}{|c|}{ Low } & \multicolumn{2}{|c|}{ Mean } & & \\
\hline & 1988 & 1989 & 1988 & 1989 & 1988 & 1989 & 1988 & 1989 \\
\hline 9 May & 19 & 19 & 8 & 7 & 13 & 13 & 3 & 67 \\
\hline 16 May & 20 & 25 & 12 & 11 & 16 & 18 & 40 & 47 \\
\hline 23 May & 26 & 25 & 12 & 12 & 19 & 18 & 19 & 37 \\
\hline 30 May & 25 & 27 & 12 & 16 & 18 & 21 & 13 & 14 \\
\hline 6 June & 24 & 25 & 14 & 15 & 19 & 20 & 1 & 78 \\
\hline 13 June & 31 & 25 & 18 & 15 & 24 & 20 & 8 & 60 \\
\hline 20 June & 29 & 29 & 17 & 18 & 23 & 23 & 18 & 1 \\
\hline 27 June & 26 & 29 & 13 & 17 & 19 & 23 & 0 & 3 \\
\hline 4 July & 31 & 29 & 17 & 20 & 24 & 24 & 0 & 67 \\
\hline 11 July & 33 & 27 & 21 & 17 & 27 & 22 & 0 & 67 \\
\hline 18 July & 34 & 28 & 21 & 18 & 27 & 23 & 87 & 5 \\
\hline 25 July & 34 & 30 & 21 & 19 & 27 & 24 & 14 & 1 \\
\hline 25 July & 34 & 30 & 22 & 19 & 27 & 24 & 0 & 4 \\
\hline 8 Aug. & 33 & 26 & 23 & 18 & 28 & 22 & 0 & 196 \\
\hline 15 Aug. & 29 & 28 & 18 & 20 & 23 & 24 & 3 & 1 \\
\hline $22 \mathrm{Aug}$. & 27 & 27 & 17 & 17 & 22 & 22 & 22 & 0 \\
\hline $29 \mathrm{Aug}$. & 26 & 27 & 16 & 18 & 21 & 22 & 17 & 45 \\
\hline
\end{tabular}

${ }^{2}$ Average temperatures for each week beginning on the date listed.

'Planting dates: 9 May, 30 May, and 13 June in 1988 and 1989. of the heads, thereby providing a better assessment of true holding potential for each genotype. Plots had been limed before plowing, and fertilizer was broadcast after plowing and incorporated with a springtooth harrow. Fertilizer was applied at the rate of $112 \mathrm{~N}-98 \mathrm{P}-93 \mathrm{~K} \mathrm{~kg}$-ha-l with an additional $56 \mathrm{~kg}$ of $\mathrm{N} /$ ha sidedressed when plants were $\approx 15 \mathrm{~cm}$ tall. Nitrogen was applied as $\mathrm{Ca}\left(\mathrm{NO}_{3}\right)_{2}$. The fertilizer mixture also included $3 \mathrm{~kg}$ $\mathrm{B}$ and $56 \mathrm{~kg} \mathrm{Mg} / \mathrm{ha}$. Rainfall was supplemented with overhead irrigation to total $25 \mathrm{~mm}$ of water per week in both seasons. High and low temperatures and precipitation were recorded daily from first seeding to final harvest.

Individual heads were tagged when they reached $10 \mathrm{~cm}$ in diameter and were cut when sepals first began to separate. The holding period of each entry was calculated as days from tagging to harvest. Heads were cut at a length of $20 \mathrm{~cm}$ from the top of the dome to the cut stem end and head weights and diameters were recorded. Harvest concentration is a measure of both the duration of the holding period and the uniformity with which a population of plants matures. Harvest concentration was estimated (Fig. 1) by plotting the mean holding periods of individual heads as they matured through time. By running horizontal lines across the graph from each holding period day, the average number of days that a particular entry may be cut at any given percentage was calculated based on each of the 10 heads being equivalent to $10 \%$ of the total.

Shade house/greenhouse experiment. In an experiment conducted in 1989, we attempted to determine what stage or stages of plant development are most critically affected by heat stress. This was measured in terms of reduction in the holding period and head weight as calculated in previous field experiments. The hybrid XPH 5168 was selected for this experiment based on its high degree of uniformity and excellent harvest concentration as determined from previous field and greenhouse plantings (unpublished).

Seeds were sown on 9 May in 36-cell flats with individual cell volume being $118 \mathrm{~cm}^{3}$ using a 1 peat : 1 vermiculite mixture. After 3 weeks, seedlings were transplanted into eightyfour 6-liter plastic pots filled with the same mix. Once potted, all plants received weekly fertilization with a complete soluble fertilizer $(15 \mathrm{~N}-16 \mathrm{P}-17 \mathrm{~K}$ plus micronutrients) at the rate of 5

Table 2. Average head weight, head diameter, and holding period for eight hybrid broccoli entries over three planting dates in 1988 and 1989 , Riverhead. N.Y.

\begin{tabular}{|c|c|c|c|c|c|c|c|c|c|c|c|c|c|c|c|c|}
\hline \multirow[b]{4}{*}{ Entry } & \multicolumn{16}{|c|}{ Planting dates } \\
\hline & \multicolumn{6}{|c|}{9 May } & \multicolumn{6}{|c|}{30 May } & \multicolumn{4}{|c|}{13 June } \\
\hline & \multicolumn{2}{|c|}{$\begin{array}{c}\text { Head } \\
\text { w t } \\
(\mathrm{g}) \\
\end{array}$} & \multicolumn{2}{|c|}{$\begin{array}{l}\text { Head } \\
\text { diam } \\
(\mathrm{cm}) \\
\end{array}$} & \multicolumn{2}{|c|}{$\begin{array}{l}\text { Holding } \\
\text { period }^{2} \\
\text { (days) }\end{array}$} & \multicolumn{2}{|c|}{$\begin{array}{c}\text { Head } \\
\text { wt } \\
(\mathrm{g}) \\
\end{array}$} & \multicolumn{2}{|c|}{$\begin{array}{l}\text { Head } \\
\text { diam } \\
(\mathrm{cm}) \\
\end{array}$} & \multicolumn{2}{|c|}{$\begin{array}{c}\text { Holding } \\
\text { period } \\
(\text { davs }) \\
\end{array}$} & \multicolumn{2}{|c|}{$\begin{array}{c}\text { Head } \\
\text { wt } \\
(\mathrm{g}) \\
\end{array}$} & \multicolumn{2}{|c|}{$\begin{array}{l}\text { Head } \\
\text { diam } \\
(\mathrm{cm}) \\
\end{array}$} \\
\hline & 1988 & 1989 & 1988 & 1989 & 1988 & 1989 & 1988 & 1989 & 1988 & 1989 & 1988 & 1989 & 1988 & 1989 & 1988 & 1989 \\
\hline Symphony & 498 & 525 & 17 & 17 & 5.5 & 4.4 & 384 & 475 & 15 & 17 & 3.2 & 3.6 & 292 & 356 & 13 & 15 \\
\hline XРH 5168 & 412 & 431 & 15 & 16 & 3.9 & 2.9 & 386 & 399 & 15 & 15 & 2.9 & 2.8 & 230 & 309 & 12 & 13 \\
\hline Excaliber & 410 & 517 & 14 & 15 & 5.6 & 3.5 & 291 & 342 & 11 & 13 & 1.9 & 2.6 & 293 & 277 & 11 & 11 \\
\hline $\begin{array}{l}\text { NVH } 521 \\
\text { Green }\end{array}$ & 651 & 673 & 20 & 20 & 6.8 & 3.8 & 522 & 580 & 18 & 18 & 4.4 & 3.5 & 734 & 368 & 22 & 15 \\
\hline Valiant & 420 & 544 & 15 & 16 & 4.5 & 3.3 & 307 & 395 & 14 & 15 & 2.4 & 2.5 & 288 & 294 & 14 & 14 \\
\hline Packman & 453 & 559 & 16 & 17 & 4.1 & 4.2 & 422 & 455 & 16 & 16 & 3.7 & 3.4 & 269 & 318 & 13 & 14 \\
\hline Sakata \#19 & 404 & 532 & 13 & 14 & 3.2 & 3.4 & 407 & 411 & 14 & 14 & 3.5 & 2.7 & 308 & 281 & 13 & 12 . \\
\hline $\begin{array}{l}\text { Sultan } \\
\text { Waller-Duncan }\end{array}$ & 489 & 486 & 15 & 15 & 5.9 & 3.5 & 419 & 332 & 14 & 13 & 5.2 & 3.3 & 337 & 344 & 13 & 13 \\
\hline LSD $(5 \%)$ & 67 & 82 & 2.6 & 1.7 & 1.3 & 0.5 & 89 & 61 & 2.3 & 1.9 & 1.2 & 0.4 & 74 & 70 & 2.7 & 2.1 \\
\hline
\end{tabular}

${ }^{2}$ Holding period measured in consecutive days from tagging heads at $10 \mathrm{~cm}$ diameter to harvest at earliest observed sepal separation. Holding data not recorded for planting date 13 June. 
$\mathrm{g} \cdot$ liter- $^{-}$. An additional application of calcium nitrate (19\% water soluble $\mathrm{Ca}$ ) at the rate of $5.3 \mathrm{~g} \cdot$ liter- $^{1}$ after 9 weeks from seeding was given to prevent apical necrosis. Standard pest control practices were used.

Based on preliminary field and greenhouse observations, we determined that the heads of hybrid XPH 5168 matured during the 11th week from seeding. Fourteen treatments, including the control, were used in a completely randomized design with six replications. The treatments consisted of $1,2,4$, and 6 week exposures to heat stress applied during the final 6 weeks of postjuvenile development. All plants were grown in a greenhouse with air at 25 to $27 \mathrm{C} / 20$ to $22 \mathrm{C}$ (day/night) cycle for the first 5 weeks to prevent premature flowering. At the onset of the 6th week, heat stress treatments were applied during various weeks until maturity by moving plants to a hot greenhouse. After each specified heat stress treatment was completed, plants were returned to the cool house. Control plants were grown continuously in the cool house.

Average air temperatures in the cooled shade house were 23 $\pm 1.9 \mathrm{C}$ day and $19 \pm 2.4 \mathrm{C}$ night. Overhead irrigation was used when needed to maintain the temperature at $\approx 23 \mathrm{C}$. The hot greenhouse was covered with translucent plastic and a $20 \%$ shade cloth was erected over the plants to equalize light levels with those in the cool house. Both houses had nearly identical amounts of natural solar radiation averaging $650 \pm 32$ $\mu \mathrm{mol} \cdot \mathrm{m}^{-2} \cdot \mathrm{s}^{-1}$ as read by a quantum sensor mounted on a model LI-1600 porometer (LI-COR, Lincoln, Neb.). Average temperatures in the hot greenhouse were $35 \pm 1.3 \mathrm{C}$ day and $23 \pm$ 0.9C night. Plants were watered frequently to avoid drying of the soil in the hot greenhouse.

Data collection for holding period was the same as for field experiments, except that individual heads were tagged when they reached $5 \mathrm{~cm}$ diameter to compensate for the reduction in head size due to container culture. Heads were cut to a length of $20 \mathrm{~cm}$ at the earliest observed sepal separation. Control plants reached this fully mature stage by the end of the 11th week from seeding. The heads were then weighed and measured. Any unusual heat stress disorders were also recorded.

Growth chamber experiment. To verify the previous results and eliminate possible confounding effects that overhead irrigation for cooling may have had on holding period due to alterations in transpirational loss and shoot apex temperature, the experiment was repeated in 1991 using only 1-week heat stress treatments and identical growth chambers for the hot and cool environments. Seeds of XPH 5168 from the 1989 seed lot kept under optimum storage conditions were planted and grown for the first 5 weeks as described above. Nine treatments, including the control, were used in a completely randomized design with six replications. An extra treatment was added due to maturation occurring 1 week later than was reported in the previous experiment. The air temperature in the hot chamber was $35 / 23 \mathrm{C}$ (day/night), while the cool chamber was kept at 23/19C (day/ night). Daylength was maintained at $14 \mathrm{~h}$ during the first 5 weeks from seeding and increased to $16 \mathrm{~h}$ during the final 6 weeks of maturation to closely follow the natural photoperiod during the first experiment. Light levels were 162 and 169 $\mu \mathrm{mol} \cdot \mathrm{m}^{-2} \cdot \mathrm{s}^{-1}$ in the cool and hot chambers, respectively. All treatments were watered daily with equal volumes of water and data were collected as described above.

Statistical analysis. Data from all experiments were subjected to a standard analysis of variance (ANOVA). Treatment means were separated with the Waller-Duncan k-ratio $t$ test at the 0.05 significance level. Quadratic P values were generated using the general linear models (GLM) procedure of SAS (1982).

\section{Results}

Field trials. During the summer of 1988, field temperatures were very high from July through early August (Table 1). Although all three plantings experienced heat stress, the timing and duration of the heat varied for each planting date. Highs ran in the 20 to $30 \mathrm{C}$ range during vegetative and early reproductive growth of the first planting followed by temperatures $>32 \mathrm{C}$ during the final weeks of maturation. The second planting was exposed to highs $>31 \mathrm{C}$ between the 6 th and 10 th weeks from seeding, and mean highs fell back $<30 \mathrm{C}$ only after the 9th week from seeding in the third planting (Table 1).

In 1988, mean holding period ranged from 3.2 to 6.8 days for the top eight entries in the first planting with four of the entries having mean holding periods of 5.5 days or longer (Table 2). However, mean holding in the second planting ranged from 1.9 to 5.2 days. The hybrid NVH 521 had significantly heavier heads than the other seven entries in all three planting dates and a significantly larger head diameter in the first and third plantings. This hybrid matured late into September in the third planting, thereby escaping the bulk of the heat stress. Some of the fluctuations in average head weight can be attributed to changes in final mean head diameter (Table 2). However, lower holding

Table 3. Mean number of days allowing 70\%, 80\%, 90\%, and 100\% field harvest in a single cut and harvest duration for 1988 and $1989 . "$

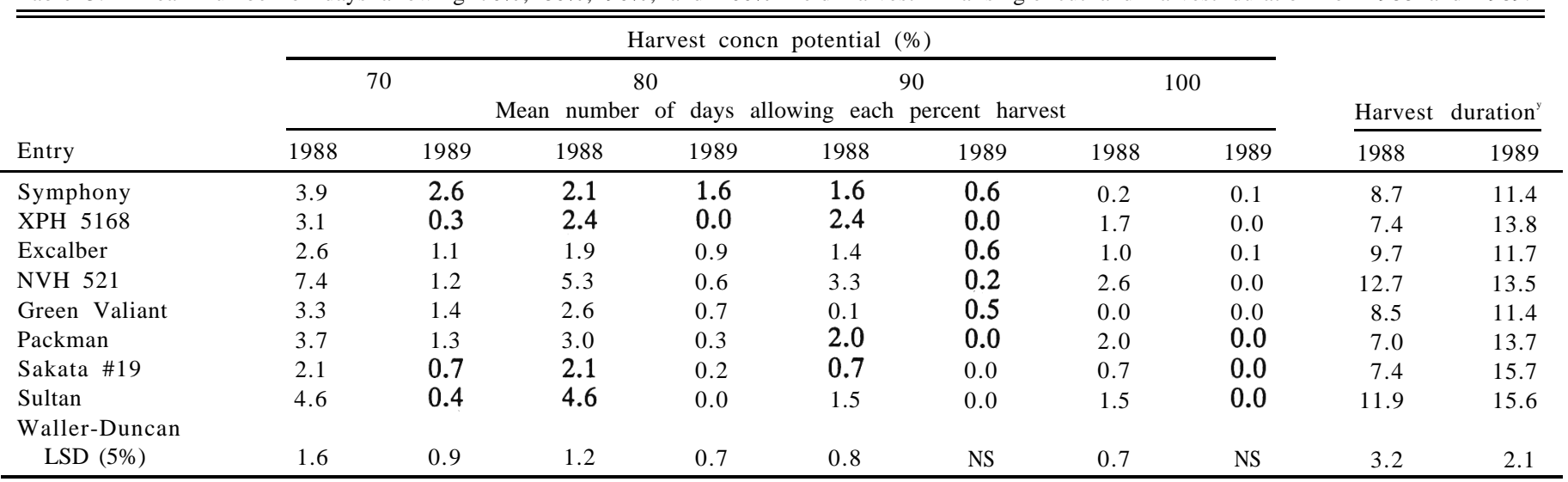

${ }^{2}$ Based on the first two planting dates, 9 May and 30 May, for each year.

'Harvest duration is the total number of days from first to last cut. 
Table 4. Mean holding, head diameter, and weight and general appearance of hybrid broccoli XPH 5168 after postjuvenile heat stress treatments in 1989 .

\begin{tabular}{|c|c|c|c|c|}
\hline $\begin{array}{l}\text { Heat stress, } \\
\text { duration, and } \\
\text { weeks applied } \\
\end{array}$ & $\begin{array}{l}\text { Holding }^{y} \\
\text { period } \\
\text { (days) } \\
\end{array}$ & $\begin{array}{l}\text { Head } \\
\text { diam } \\
(\mathrm{cm}) \\
\end{array}$ & $\begin{array}{c}\text { He a d } \\
\text { w t } \\
(\mathrm{g}) \\
\end{array}$ & $\begin{array}{c}\text { Appearance } \\
\text { of heads }\end{array}$ \\
\hline None & 7.2 & 13.5 & 160 & Marketable quality \\
\hline \multicolumn{5}{|l|}{1 week } \\
\hline $\begin{array}{l}6^{x} \\
7 \\
8^{x} \\
9 \\
10 \\
11^{\prime \prime}\end{array}$ & $\begin{array}{l}7.7 \\
4.3 \\
2.0 \\
52.0 \\
5.5 \\
6.5\end{array}$ & $\begin{array}{r}13.3 \\
8.5 \\
6.8 \\
9.8 \\
11.0 \\
11.0\end{array}$ & $\begin{array}{r}141 \\
101 \\
97 \\
118 \\
125 \\
132\end{array}$ & $\begin{array}{l}\text { Marketable quality } \\
\text { Irregular/loose } \\
\text { Small/puffy bud } \\
\text { Flat/long stalks } \\
\text { Slight puffy bud } \\
\text { Marketable quality }\end{array}$ \\
\hline \multicolumn{5}{|l|}{2 weeks } \\
\hline $\begin{array}{l}6-7 \\
8-9 \\
10-11\end{array}$ & $\begin{array}{l}3.8 \\
1.5 \\
4.5\end{array}$ & $\begin{array}{l}8.0 \\
6.3 \\
9.5\end{array}$ & $\begin{array}{r}101 \\
96 \\
103\end{array}$ & $\begin{array}{l}\text { Irregular } \\
\text { Small/puffy bud } \\
\text { Midhead flat }\end{array}$ \\
\hline \multicolumn{5}{|l|}{4 weeks } \\
\hline $\begin{array}{l}6-9 \\
7-10 \\
8-1 \quad 1\end{array}$ & $\begin{array}{l}2.0 \\
1.5 \\
1.2\end{array}$ & $\begin{array}{l}6.8 \\
6.2 \\
5.5\end{array}$ & $\begin{array}{l}90 \\
84 \\
86\end{array}$ & $\begin{array}{l}\text { Loose/leafyhead } \\
\text { Loose/leafyhead } \\
\text { Small/irregular }\end{array}$ \\
\hline \multicolumn{5}{|l|}{6 weeks } \\
\hline $\begin{array}{l}\text { 6-11 } \\
\text { Waller-Duncan } \\
\text { LSD }(5 \%)\end{array}$ & 0.5 & 4.8 & 81 & Very small/loose \\
\hline
\end{tabular}

${ }^{2}$ Weeks after seeding when exposed to $35 \mathrm{C}$ daily highs in greenhouse. 'Holding period measured in mean consecutive days from tagging heads at $5 \mathrm{~cm}$ diameter to cutting at earliest observed sepal separation.

${ }^{x}$ Vegetative plant growth at 6th week from seeding. Early reproductive development at 8th week, with immature head measuring 5 to $10 \mathrm{~mm}$ in diameter. Final week of maturation of inflorescence during 11th week.

values were not consistently correlated with smaller head diameters.

For the 32 entries that were not advanced for testing in the second season, average head weight at harvest ranged from 183 to $415 \mathrm{~g}$, average head diameter ranged from 5 to $16 \mathrm{~cm}$, and mean holding periods ranged from 0.4 to 3.1 days. For these entries, there was no general trend for hybrids bred for heat tolerance to perform better than commercial cultivars. In fact, the worst entry with mean head diameter of $7 \mathrm{~cm}$ and mean holding of only 0.4 days in the second planting was an experimental hybrid bred for heat tolerance. Two cultivars in the top eight of 1988 not bred specifically for heat tolerance, 'Green Valiant' and 'Packman', performed similarly compared to the six experimental hybrids (Table 2). The hybrids 'Symphony', 'Excaliber', and 'Sultan' were released as cultivars during the course of this research. Experimental hybrids XPH 5168, NW-I 521, and Sakata \#19 were discontinued.

In 1989, frequent heavy rains became the critical environmental stress factor rather than heat. Although stand and plant populations were constant in both years, flooding decreased plant biomass and vigor in the lowest areas of the field in 1989. Mean highs did not rise >30C during 1989 (Table 1). Mean holding ranged from 2.9 to 4.4 days in the first planting and only from 2.5 to 3.6 days in the second planting (Table 2). The hybrid NVH 521 again had significantly heavier heads than the other seven entries in the first two plantings, but was not significantly different from 'Symphony', XPH 5168, 'Packman', or 'Sultan' in the third planting. The dramatic decrease in head weight for
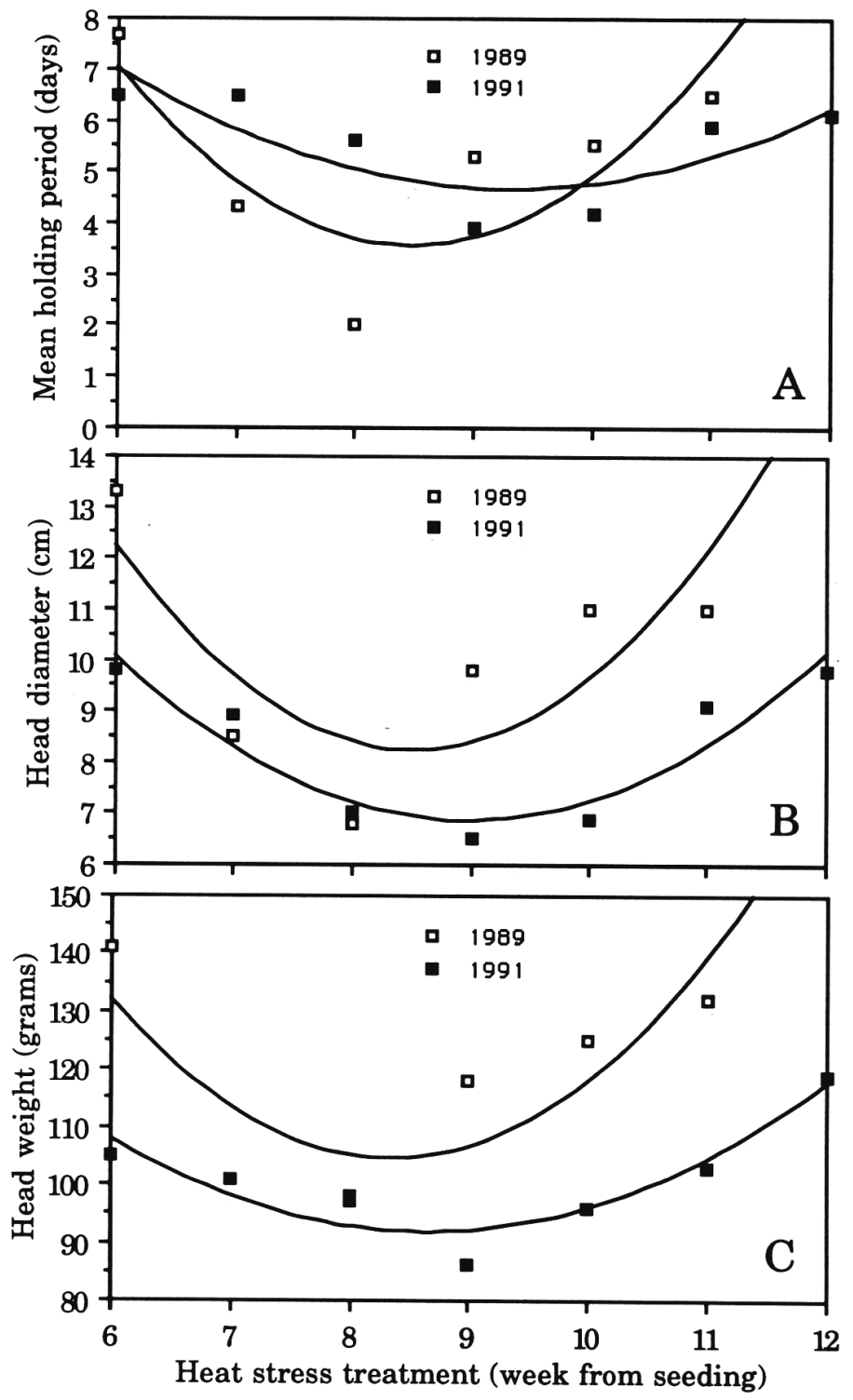

Fig. 2. Growth response measured in (A) mean holding period (days), (B) average head diameter at harvest (centimeters), and (C) mean head weight (grams) following exposure of hybrid broccoli XPH 5168 to 1 week of heat stress at $35 \mathrm{C}$. Data from both years show a highly significant $(P \leq 0.001)$ quadratic fit.

NVH 521 in the third planting was most likely attributable to extensive flooding.

Harvest concentration of NVH 521 was 3 days to cut $100 \%$ and 4 days to cut at least $80 \%$ of the heads, while that of the more erratic maturing line, Sunre 8023, was only 2 days to cut $50 \%$ (Fig. 1). Pooled data from the first two planting dates in 1988 indicate that average harvest concentration values ranging from 2 to 5 days to cut $80 \%$ of the total were possible for the top eight entries (Table 3). The high degree of heat stress during 1988 resulted in significant differences in harvest concentration between entries (Table 3). There was less harvest uniformity in 1989 than in 1988. 'Symphony' was the only exception to this general trend, maintaining moderately good harvest concentration and holding values throughout the season. No significant differences were found between the eight entries in 1989 for $90 \%$ and $100 \%$ harvest concentration potential (Table 3). 

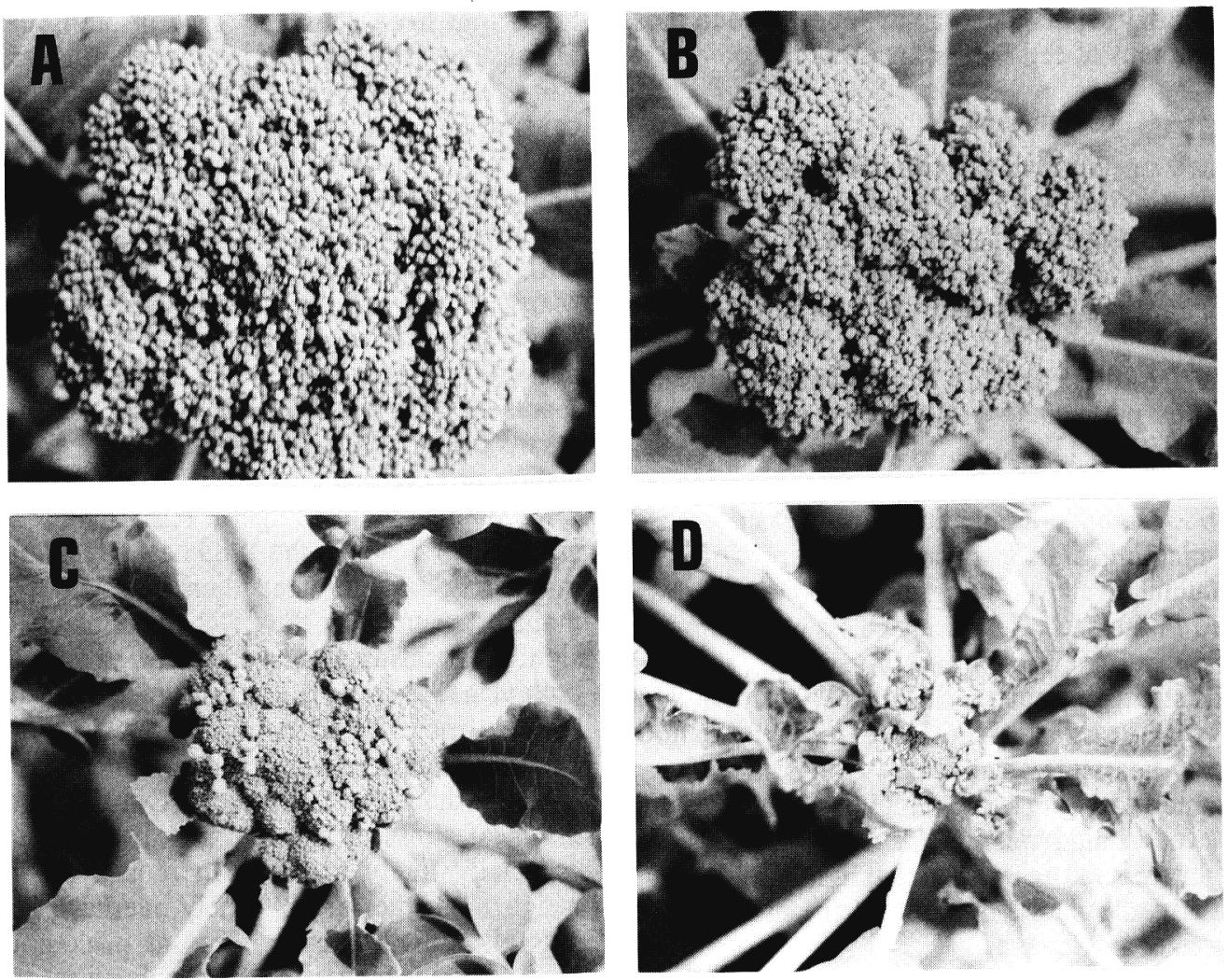

Fig. 3. Hybrid broccoli XPH 5168 heads at harvest 11 weeks from seeding. Treatments shown photographed at the same distance from the tip of the heads are: (A) continuous cool conditions; $13 \mathrm{~cm}$ diameter with mature, uniform buds. (B) single week of heat stress during the final week of maturation; $11 \mathrm{~cm}$ diameter with mature, uniform buds. (C) single week of heat stress at 3 weeks before harvest; $7 \mathrm{~cm}$ diameter with immature and sporatic puffy buds, and (D) continuous heat stress, $4 \mathrm{~cm}$ diameter with only immature buds.

Shade house/greenhouse experiment. For the 1-week treatments in the 1989 experiment, mean holding period was lowest following exposure to heat stress during the 8 th week from seeding (Table 4), when the immature head measured 5 to 10 $\mathrm{mm}$ in diameter. Average head diameter was also lowest after the 8th week treatment, while mean head weight was not sig-

Table 5. Mean holding, head diameter, and weight and general appearance of hybrid broccoli XPH 5168 after postjuvenile heat stress treatments in 1991.

\begin{tabular}{lcccc}
\hline \hline $\begin{array}{l}\text { Weeks } \\
\text { heat stress } \\
\text { applied }^{2}\end{array}$ & $\begin{array}{c}\text { Holding }^{y} \\
\text { period } \\
\text { days) }\end{array}$ & $\begin{array}{c}\text { Head } \\
\text { diam } \\
(\mathrm{cm})\end{array}$ & $\begin{array}{c}\text { He ad } \\
\text { wt } \\
(\mathrm{g})\end{array}$ & $\begin{array}{c}\text { Appearance } \\
\text { of heads }\end{array}$ \\
\hline None & 6.7 & 10.2 & 122 & Marketable quality \\
$6^{\mathbf{x}}$ & 6.5 & 9.8 & 10.5 & Marketable quality \\
$\mathbf{7}$ & 6.5 & 8.9 & 101 & Slightly irregular \\
8 & 5.6 & 7.0 & 98 & Irregular/loose \\
$9^{\mathbf{x}}$ & 3.9 & 6.5 & 86 & Small/puffy buds \\
10 & 4.2 & 6.9 & 96 & Irregular/puffy \\
11 & 5.9 & 9.1 & 103 & Marginal quality \\
$12^{\mathbf{x}}$ & 6.1 & 9.8 & 119 & Marketable quality \\
$6-1$ & 0.3 & 4.2 & 78 & Very small/loose \\
Waller-Duncan & & & & \\
LSD (5\%) & 0.8 & 1.6 & 19 & \\
\hline
\end{tabular}

${ }^{2}$ Weeks after seeding exposed to $35 \mathrm{C}$ daily high temperatures. "Holding period measured in mean consecutive days from tagging heads at $5 \mathrm{~cm}$ diameter to cutting at earliest observed sepal separation.

${ }^{x}$ Vegetative plant growth at 6 th week from seeding. Early reproductive development at 9th week, with immature head measuring 5 to $10 \mathrm{~mm}$ in diameter. Final week of maturation of inflorescence during 12th week. nificantly different for the 7th and 8th week treatments. Although the 6 th and 11 th week treatments resulted in market quality heads, the mean head weight for these treatments was significantly lower than the control grown without heat stress (Table 4). The data for 1 -week treatments indicate a highly significant $(P \leq 0.001)$ quadratic relationship (Fig. 2).

For the 2 -week treatments, mean holding period and head diameter were lowest following exposure to heat stress during weeks eight through nine (Table 4), while mean head weights were similar for all three 2 -week treatments. Mean holding period, head diameter, and weight were similar for the three 4week treatments. These values were also similar to the eighth l-week and weeks eight through nine for the 2 -week treatment values (Table 4). Mean holding was the lowest for the final 4and 6-week treatments. All 2-, 4-, and 6-week treatments resulted in small heads of very poor quality. Increased growth of vegetative axillary shoots was also observed in many of the prolonged heat treatments. Mature heads from four of the treatments were photographed at the same distance from each head (Fig. 3)

Growth chamber experiment. When the experiment from the greenhouse in 1989 was repeated in 1991, but in a growth chamber, significant differences were observed for holding period, head diameter, and weight (Table 5). While a quadratic fit similar to the 1989 data was noted (Fig. 2), mean holding was not significantly different for the 9 th and 10th week treatments (Table 5). The 6-week treatment resulted in the lowest mean holding and head diameter values, while mean head weight for the 6-week treatment was similar to that for the 9th and 10th week treatments. Heat stress during 8th week in 1989 resulted in 
aberrant heads with puffy sepals identical in appearance to those in the 9th week treatment of the 1991 experiment.

\section{Discussion}

The data collected on cultivar screening for heat tolerance and holding ability combined with the results from the experiments relating heat tolerance to specific stages of growth and development suggest that both timing and duration of heat stress are important in determining the pattern of broccoli floral development.

Cultivar screening results over both years of this study indicate that some entries performed well under a wide range of temperatures and conditions (Table 1). Most of the forty entries tested, however, performed poorly during the high temperatures experienced in 1988. High air temperatures only during maturation in the first planting did not decrease holding ability as much as earlier or cumulative heat during the reproductive growth stages that occurred in the second planting. This trend was true for seven out of eight entries (Table 2). Cultivars such as 'Symphony' had a consistently strong performance over all three planting dates for both years in Riverhead. This hybrid, however, exhibited poor heat tolerance when grown in Geneva, N.Y., during the same years (Dickson, unpublished data). Upon inspection of Geneva weather records for 1988, it was noted that while daily high temperatures were only slightly higher than values recorded in Riverhead, the duration of the high temperatures was much longer in Geneva.

Perhaps as important as good holding ability is the potential for a cultivar to provide consistently good harvest concentration. Harvest concentration was particularity poor in the second planting of 1989, effectively reducing the mean values when pooled with those of the first planting (Table 2). Early heavy rains and low temperatures resulted in nonuniform seedling growth. During the 1988 season, timely irrigation and steady higher temperatures may have provided a greater degree of control over the growth rate. Somewhat heavier heads were produced in the 1989 season, while holding periods remained similar to or even lower than in 1988 (Table 1). A marked decrease in the incidence of hollow stem coupled with greater head turgidity in 1989 may have contributed to higher head weight. Since B levels were tested as adequate in both seasons, the tendency for hollow stem to occur in 1988 was probably due to rapid growth rate. This was confirmed by both harvest date and harvest duration (Table 3 ).

The greatest disruption in normal growth and development of broccoli by heat stress appears to occur $\approx 3$ weeks before harvest. This may vary, depending on the maturity date of the cultivar and the growth rate. The head measures $\approx 5$ to $10 \mathrm{~mm}$ in diameter at this stage as confirmed by field observations and greenhouse data (Tables 4 and 5). Mature heads from the treatments receiving heat stress either during the 6th week or during the final week of head maturation exhibited uniform bud maturation similar to heads matured under constant cool temperatures (Fig. 3). However, mean head weights for these treatments were lower than those grown under constant cool conditions (Tables 4 and 5).

The occurrence of a small group of puffy or enlarged sepals on an otherwise immature head marked the typical growth abnormality observed when heat stress was applied during the 5 to $10 \mathrm{~mm}$ head diameter stage in both years tested (Fig, 3C). Disruption of time periods bracketing the 5 to $10 \mathrm{~mm}$ diameter stage with heat stress typically resulted in uneven florette length, causing loose or irregularly shaped heads. Both of these symptoms were observed for many of the 40 hybrids tested in the field during 1988, as well as other variations including extremely elongated sepals occurring throughout the entire head. Different hybrids may respond quite differently to heat stress. Many of the experimental hybrids bred specifically for heat tolerance performed poorly during the 1988 season in Riverhead. We emphasize that data from these heat stress experiments represent the effects on one hybrid, XPH 5168. Likewise, the results of the cultivar screening presented here are indicative of testing in only one location over 2 years.

While high ambient light levels may have contributed to larger and heavier heads in the 1989 heat stress study, the overall trend in holding period, head diameter, and weight reductions remained the same in the 1991 experiment (Fig. 2). Statistically significant differences were detected for all three categories in both years. However, a greater range of values was recorded in 1989. A major difference in the 1991 experiment was a l-week delay in maturity, which may be attributable to the lower light levels in the growth chambers. Our data provide good evidence that heat stress during the 5 to $10 \mathrm{~mm}$ head diameter stage is especially likely to result in reductions in holding and head weight. Whether or not timely overhead irrigation applied during this critical growth stage at peak hours of daytime heat would alleviate some of the problems associated with heat stress in the field remains to be tested. Other potential methods to reduce the problems of heat stress include cultivar selection and planting dates that minimize the amount of heat during the critical stage of growth or simply avoidance of heat entirely.

\section{Literature Cited}

Chung, B. 1985. The effects of sowing time and plant density on the once-over harvest yields of broccoli. J. Hort. Sci. 60(1):57-64.

Fontes, M. R., J.L. Ozbun, and S. Sadik. 1967. Influence of temperature on initiation of floral primordia in green sprouting broccoli. Proc. Amer. Soc. Hort. Sci. 91:315-320.

Fujime, Y. and T. Hirose. 1984. Studies on the thermal conditions of curd formation and development in cauliflower and broccoli. Tech. Bul. Agr. Kagawa Univ., Japan. 35(2):111-120.

Gauss, J.F. and G.A. Taylor. 1969. Environmental factors influencing reproductive differential and the subsequent formation of the inflorescence of Brassica oleracea L. var. italica Plenck, CV. Coastal. J. Amer. Sot. Hort. Sci. 94(3):275-280.

Knott, J.E. and G.C. Hanna. 1949. Yield of broccoli strains: Investigations on the influence of summer planting dates on yield of four strains of broccoli. California Agr. 3:10-12.

Love, J. 1986. U.S. vegetable industry in the 1980s. Natl. Food Rev. U.S. Dept. of Agr. Econ. Res. Serv. (31) 7-11.

Miller, C. H., T.R. Konsler, and W.J. Lament, 1985. Cold stress influence on premature flowering of broccoli. HortScience. 202:193195.

SAS User's guide: Statistics. 1982 (ed.). SAS Institute, Cary, N.C.

Shattuck, V. I., B.J. Shelp, A. Loughton, and R. Baker. 1986. Environmental stability of yield and hollow stem in broccoli (Brassica oleracea var. italica). Can. J. Plant Sci. 66:683-688.

Sieczka, J. B., D.W. Heather, and J.F. Creighton. 1989.1988 Broccoli results: Variety and planting date studies. Veg. Crops Rpt. 375. L.I. Horticultural Research Lab, Riverhead, N.Y. 